\title{
Identifikasi Kematangan Buah Kelapa Sawit Berdasarkan Warna RGB Dan HSV Menggunakan Metode K-Means Clustering
}

\author{
Elok Faiqotul Himmah $^{1)}$, Maura Widyaningsih' ${ }^{2)}$ Maysaroh $^{3)}$ \\ ${ }^{12) 3)}$ Prodi Teknik Informatika, STMIK Palangkaraya \\ Jl. George Obos No. 114, Palangka Raya \\ 1) el.faiqotul@gmail.com \\ 2) maurawidya@gmail.com \\ 3) maysaroh0296@gmail.com
}

\begin{abstract}
Abstrak
Kelapa sawit merupakan salah satu tumbuhan tropis penghasil minyak nabati yang banyak dibudidayakan. Ketepatan dalam menentukan tingkat kematangan buah kelapa sawit menentukan kualitas hasil panen tumbuhan ini. Penelitian ini memanfaatkan pengolahan citra digital untuk mengidentifikasi kematangan buah kelapa sawit berdasarkan warna RGB (Red, Green, Blue) dan HSV (Hue, Saturation, Value). Citra berupa foto buah kelapa sawit yang diambil dengan kamera digital diolah dengan perangkat lunak MATLAB kemudian dianalisis menggunakan metode klasifikasi $K$ Means Clustering untuk mendapatkan perbandingan hasil ekstraksi ciri RGB dan HSV. Hasil penelitian mampu membedakan tingkat kematangan buah kelapa sawit yaitu mentah, cukup matang, dan matang dengan tingkat keakuratan total pada data uji dan data latih sebesar $64.58 \%$.
\end{abstract}

Kata kunci: identifikasi kematangan, kelapa sawit, RGB, HSV, K-Means Clustering

\begin{abstract}
Oil palm is one of the most cultivated vegetable oil-producing tropical plants. The accuracy in determining the maturity level of oil palm fruit determines the quality of the yield of this plant. This study utilized digital image processing to identify the maturity of oil palm fruit based on RGB (Red, Green, Blue) and HSV (Hue, Saturation, Value) colors. An image in the form of a photo of oil palm fruit taken with a digital camera is processed with MATLAB software and then analyzed using the K-Means Clustering classification method to obtain a comparison of the extraction results of RGB and HSV features. The results of the study were able to distinguish the maturity level of oil palm fruit, namely raw, sufficiently ripe, and ripe with a total accuracy level of the test data and training data of $64.58 \%$.
\end{abstract}

Keywords: identification of maturity, palm oil, RGB, HSV, K-Means Clustering

\section{PENDAHULUAN}

Kelapa sawit merupakan salah satu tumbuhan penghasil minyak nabati yang banyak diminati untuk dibudidayakan oleh masyarakat di Indonesia, sebab tumbuhan ini memiliki potensi yang cukup besar dalam meningkatkan perekonomian dan kesejahteraan sosial bagi masyarakat. Sebagai akibatnya, perkebunan kelapa sawit di Indonesia semakin berkembang dan saat ini telah menyebar di 22 provinsi yang terletak di berbagai pulau di Indonesia [1].

Hasil perkebunan kelapa sawit berupa minyak sawit dan turunannya menjadi komoditas ekspor yang terus memberikan sumbangan yang sangat besar bagi perekonomian nasional. Selain penghasil minyak sawit terbesar, pada tahun 2018, Indonesia menjadi pengekspor minyak sawit terbesar di dunia [2].

Keberhasilan budidaya kelapa sawit salah satunya ditentukan oleh pengelolaan atau manajemen panen yang baik dan benar. Ketepatan dalam menentukan kematangan buah kelapa sawit yang dipanen sangat diperlukan [3]. Perbedaan persepsi petani atau penyeleksi menjadi salah satu faktor penyebab kurang optimalnya proses pemilihan buah kelapa sawit dengan tingkat kematangan yang 
tepat. Oleh karena itu, diperlukan cara yang lebih efektif untuk mengatasi hal tersebut. Pengolahan citra merupakan cara yang efektif untuk mengidentifikasi tingkat kematangan buah kelapa sawit.

Penelitian ini memanfaatkan pengolahan citra digital untuk membuat sebuah sistem yang dapat mengidentifikasi kematangan buah kelapa sawit berdasarkan warna RGB (Red, Green, Blue) dan HSV (Hue, Saturation, Value). Citra berupa foto buah kelapa sawit yang diambil dengan kamera digital diolah dengan menggunakan perangkat lunak MATLAB kemudian dianalisis dengan metode klasifikasi K-Means Clustering untuk mendapatkan perbandingan hasil ekstraksi ciri RGB dan HSV.

Penelitian sejenis pernah dilakukan untuk menilai tingkat kematangan buah kelapa sawit dengan menggunakan model warna RGB dan teknik logika fuzzy. Efisiensi keseluruhan hasil simulasi untuk membedakan buah kelapa sawit mentah, matang, dan terlalu matang diperoleh sebesar $88.7 \%$ [4]. Selain itu, metode K-Means Clustering juga digunakan dalam [5] untuk mengidentifikasi kualitas buah-buahan berdasarkan warna RGB. Hasil penelitian berhasil mengidentifikasi buah yang baik dan buruk dengan tingkat keakuratan $80 \%$.

Langkah yang akan digunakan dalam penelitian ini adalah: 1) pengambilan citra, 2) perbaikan citra, 3) proses segmentasi, 4) ekstraksi ciri dan 5) identifikasi. Objek akan diambil dalam bentuk citra digital dalam format jpg. Perbaikan citra dengan melakukan pelabelan dan resize serta perubahan intensitas piksel dengan fungsi grayscale. Hasil perbaikan citra akan disegmentasi untuk memisahkan objek dengan background kemudian dilakukan proses ekstraksi ciri dengan RGB dan HSV. Langkah terakhir adalah pengenalan objek (identifikasi) dengan menggunakan metode $\mathrm{K}$-means Clustering.

\section{TINJAUAN PUSTAKA}

Bagian ini memuat teori-teori pendukung dari metode yang diusulkan untuk pemecahan suatu masalah dan/atau pengembangan dari metode tersebut, yang didasarkan dari referensi yang jelas (buku, jurnal, prosiding dan artikel ilmiah lainnya).

\subsection{Kelapa Sawit}

Kelapa sawit (Elaeis guineensis Jacq.) merupakan tanaman golongan plasma yang termasuk tanaman tahunan. Tanaman ini berasal dari Negara Afrika Barat dan dapat tumbuh subur di daerah-daerah tropis seperti di Indonesia, Malaysia, Thailand dan Papua Nugini [6].

Buah kelapa sawit mempunyai warna yang bervariasi dari hitam, ungu, hingga merah. Buah kelapa sawit berkualitas baik adalah buah yang dipanen pada tingkat kematangan yang tepat. Warna buah kelapa sawit serta banyaknya buah yang lepas dari tandan menjadi penentu kematangan buah yaitu:

1) Buah mentah, jika buah berwana hitam dan tidak ada yang lepas dari tandan.

2) Buah cukup matang, jika buah berwarna kemerahan dan lepas dari tandan sebanyak $12,5-25,0 \%$.

3) Buah matang, jika buah berwarna merah mengkilat dan lepas dari tandan sebanyak $26-50 \%$.

\subsection{Digital Image Processing}

Digital Image Processing atau pengolahan citra digital merupakan teknik pengolahan gambar atau citra dengan menggunakan berbagai algoritma. Citra berupa foto yang tampak sedikit gelap dapat diolah menjadi lebih terang adalah contoh proses yang dapat dilakukan melalui pengolahan citra digital [7]. Pengolahan citra digital telah diterapkan di banyak aplikasi dan diberbagai bidang, tidak hanya sebatas mengatur revolusi spasial suatu gambar dan meningkatkan kecerahan foto tetapi juga mampu menganalisis hal-hal yang hanya bisa dilihat oleh kamera namun tidak dapat dilihat secara kasat mata oleh manusia seperti spektrum warna yang ditampilkan oleh gelombang elektromagnetik [8].

\subsection{Warna RGB (Red, Green, Blue)}

Kepekaan mata manusia terhadap warna merah, hijau, dan biru mendasari teori citra RGB (truecolor). Bila dilakukan pencampuran ketiga unsur warna tersebut dapat menghasilkan warna lain yang disebut additive color. Pengaturan warna RGB (Red, Green, Blue) menggunakan skala mulai dari 0 sampai dengan 255 . Warna dari tiap piksel ditentukan dengan kombinasi intensitas red, green dan blue yang disimpan di tiap saluran warna di lokasi piksel tertentu. Format file grafik 
menyimpan RGB image sebagai 24-bit image, dengan komponen red, green dan blue masingmasing 8 bit [9]. Normalisasi unsur warna ditentukan oleh Persamaan (1), (2), dan (3) berikut:

$r=\frac{R}{R+G+B}$
$g=\frac{G}{R+G+B}$
$b=\frac{B}{R+G+B}$

Keterangan: $r=$ normalisasi $r e d, g=$ normalisasi green, $b=$ normalisasi blue.

\subsection{Warna HSV (Hue, Saturation dan Value)}

Selain RGB, model yang digunakan dalam analisis warna pada pengolahan citra digital adalah HSV yaitu Hue, Saturation dan Value. Hue menyatakan warna sebenarnya, seperti merah, violet, dan kuning yang digunakan untuk menentukan kemerahan (redness), kehijauan (greenness), dan lainnya. Saturation atau chroma, artinya kemurnian atau kekuatan warna. Value menyatakan kecerahan warna dan nilainya berkisar antara 0-100 \%. Jika value bernilai 0 maka warnanya akan menjadi hitam, semakin besar nilai value maka semakin cerah dan muncul variasi-variasi baru dari warna tersebut [10]. Konversi RGB menjadi HSV dirumuskan oleh Persamaan (4), (5) dan (6).

$$
\begin{aligned}
& H=\tan \left(\frac{3(G-B)}{(R-B)+(R-B)}\right) \\
& S=1-\frac{\min (R, G, B)}{v} \\
& V=\frac{R+G+B}{3}
\end{aligned}
$$

\subsection{Algoritma K-Means Clustering}

Algoritma K-Means Clustering merupakan algoritma yang mengelompokkan data ke dalam sejumlah cluster yang telah ditentukan sebelumnya. Algoritma ini paling banyak digunakan dalam datamining. Tujuan dari $K$-means adalah untuk mengurangi penjumlahan kuadrat jarak antara titik data dan pusat cluster masing-masing [11]. Tahapan yang dilakukan pada algoritma dasar $K$-Means Clustering dimulai dengan (1) penentuan jumlah cluster $\mathrm{k}$, (2) penentuan nilai pusat (centroid), untuk penentuan nilai awal centroid untuk awal iterasi dilakukan secara acak, (3) perhitungan jarak antara titik centroid dengan titik setiap objek, (3) pengelompokan objek, (4) kembali ke tahap 2, perulangan dilakukan hingga nilai centroid yang dihasilkan tetap dan anggota cluster tidak berpindah ke cluster lain [12].

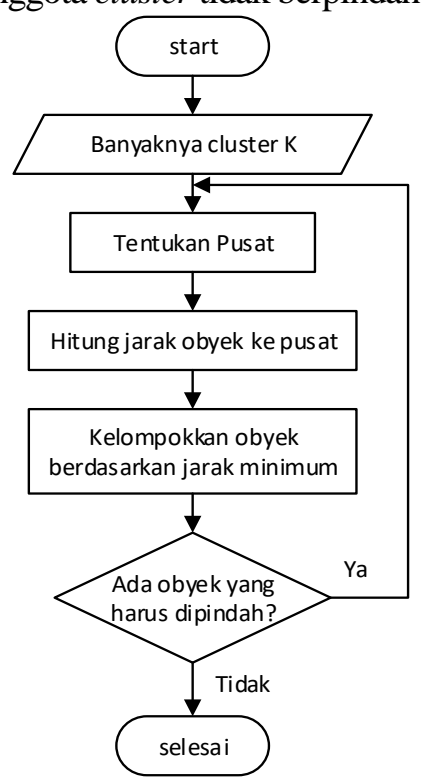

Gambar 1. Flowchart metode K-Means clustering 
Persamaan (7) merupakan perhitungan Eucludian Distance dalam [12].

$d(\mathrm{x}, \mathrm{y})=\sqrt{(x 1-x 2)^{2}+(y 1-y 2)^{2}}+\cdots \cdot(y n-y n)^{2}$

Keterangan: $n=$ banyaknya atribut, $\mathrm{x}=$ vektor atribut real suatu data, $\mathrm{y}=$ vektor atribut hasil perhitungan (output) suatu data, $d(\mathrm{x}, \mathrm{y})=$ Euclidean Distance dari $\mathrm{x}$ dan $\mathrm{y}$.

\section{METODE PENELITIAN}

Metode yang digunakan dalam penelitian ini adalah sebagai berikut:

\subsection{Objek Penelitian}

Penelitian dilaksanakan di perkebunan kelapa sawit di Desa Bukit Harapan Kecamatan Parenggean Kabupaten Kotawaringin Timur, Kalimantan Tengah dengan objek yang diteliti adalah buah kelapa sawit.

\subsection{Pengumpulan Data}

Pengumpulan data dalam penelitian ini dilakukan dengan teknik observasi dan wawancara. Data berupa foto buah kelapa sawit diambil secara langsung di perkebunan kelapa sawit milik Bapak Mansur di Desa Bukit Harapan Kecamatan Parenggean Kabupaten Kotawaringin Timur, sedangkan keterangan-keterangan tentang data buah matang, cukup matang, dan mentah diperoleh dari hasil wawancara dengan pemilik perkebunan tersebut. Sebanyak 54.5\% atau 24 dari 44 data berupa foto buah kelapa sawit yang diperoleh digunakan sebagai data latih dan sebanyak $45.5 \%$ atau 20 dari 44 data tersebut digunakan sebagai data uji.

\subsection{Pemodelan Sistem}

Berikut dijelaskan alur dari kerja sistem berdasarkan tahap pemodelan sistem yang penulis gunakan. Gambar 2 merupakan block diagram pemrosesan data identifikasi kematangan buah kelapa sawit berdasarkan warna RGB dan HSV.

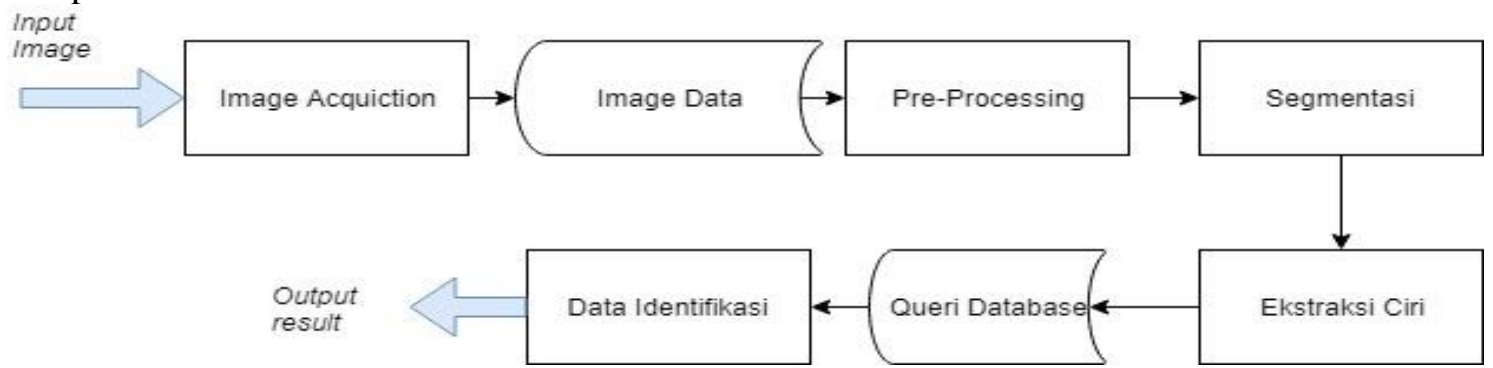

Gambar 2. Block diagram pemrosesan data

Penjelasan mengenai block diagram pada Gambar 2 dapat diuraikan sebagai berikut:

1. Image Acquisition, pada tahap ini dilakukan pengambilan beberapa citra buah kelapa sawit dengan peralatan digital, sehingga citra tersebut berekstensi "jpg".

2. Image Data, pada tahap ini dilakukan pengaturan citra buah kelapa sawit dalam database queri yang akan diproses ke pre-processing.

3. Pre-processing, merupakan proses awal pengolahan citra. Pada tahap ini dilakukan pelabelan dan resize dan perubahan citra RGB buah kelapa sawit ke grayscale.

4. Segmentasi, pada tahap ini dilakukan pemisahan antara objek yang dikehendaki dengan objek lain yang tidak dikehendaki.

5. Ekstraksi Ciri, tahap ini merupakan tahap untuk mendapatkan nilai ciri masing-masing citra, baik data latih maupun data uji.

6. Queri Database, pada tahap ini dilakukan pengaturan database citra latih buah kelapa sawit untuk memudahkan pengenalan pada klasifikasi data. 


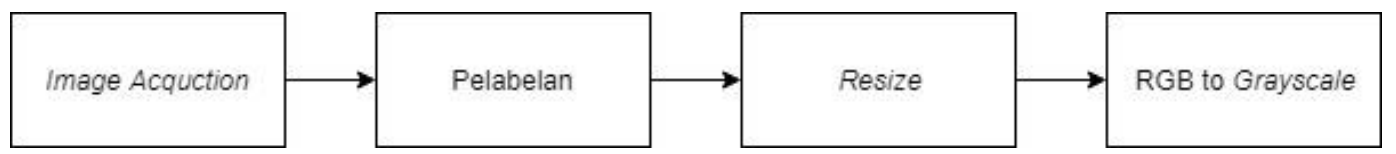

(a) Block diagram pre-processing

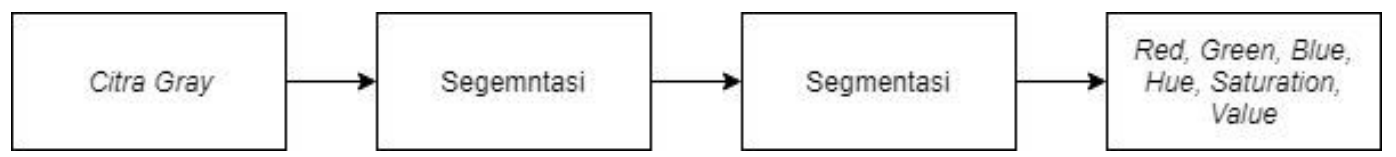

(b) Block diagram ekstraksi ciri

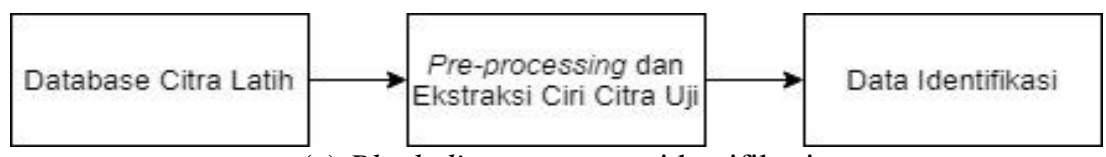

(c) Block diagram proses identifikasi

Gambar 5. Rincian proses pengolahan citra buah kelapa sawit di dalam sistem

Proses akhir untuk mengetahui hasil uji kategori buah kelapa sawit terhadap kemiripan yang ada di database queri menghasilkan data identifikasi. Hasil akhir berupa kategori kelapa sawit matang, cukup matang dan mentah yang diperoleh dari data citra uji buah kelapa sawit. Gambaran sistem identifikasi tingkat kematangan buah kelapa sawit dengan algoritma $\mathrm{K}$-Means Clustering dapat dilihat pada Gambar 6. Terdapat beberapa proses yang dibangun oleh algoritma pendukungnya, yaitu segmentasi citra dan fungsi ekstraksi ciri red, green, blue, hue, saturation dan value. Proses klasifikasi dengan $K$-Means Clustering merupakan proses pengklasifikasian vektor fitur buah kelapa sawit menjadi 3 kelas atau kategori yaitu matang, cukup matang dan mentah. Proses pengujian, yaitu proses membandingkan fitur masukan baru dengan fitur yang ada pada referensi yang sebelumnya sudah dilatih kepada sistem.

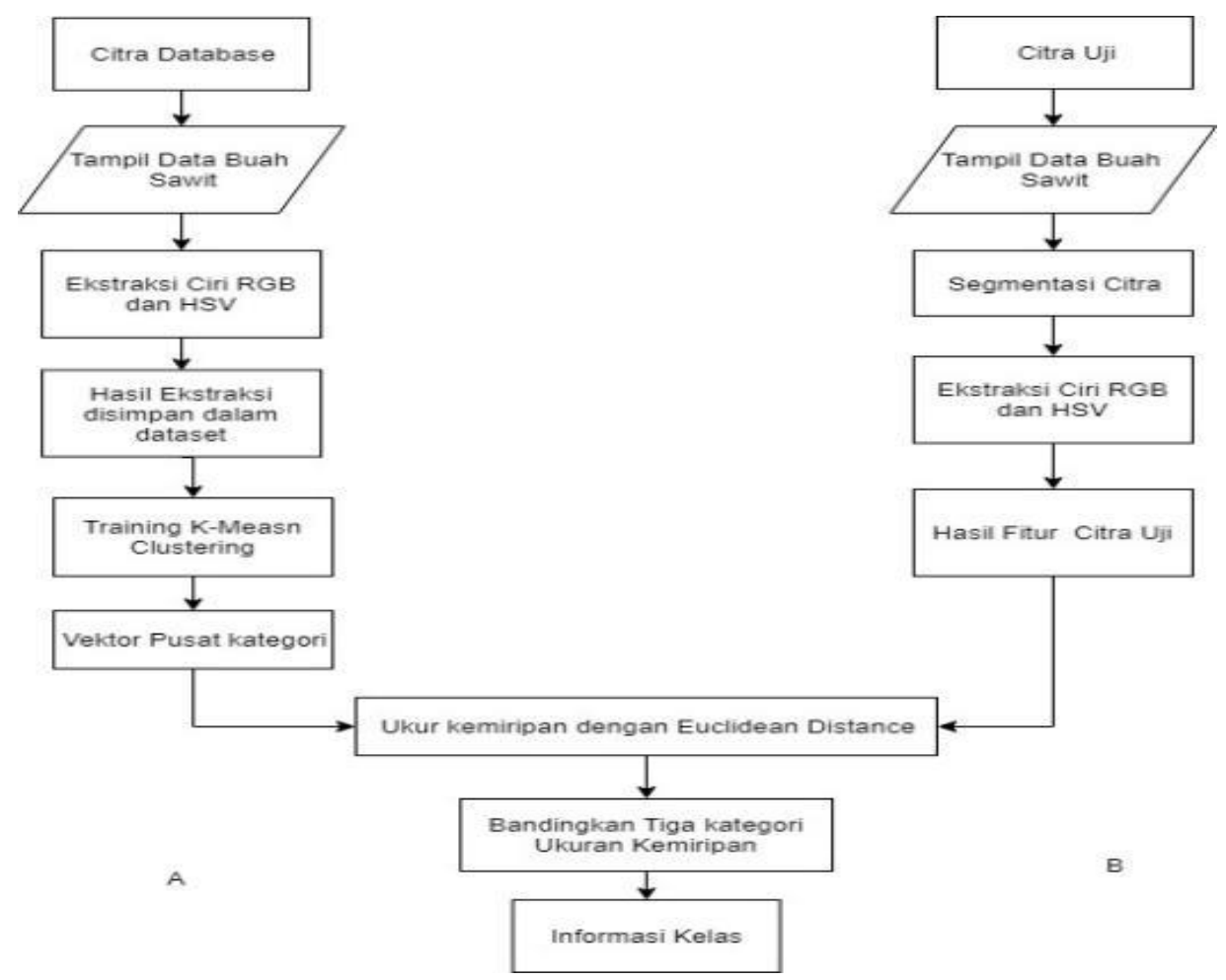

Gambar 6. Diagram alir pelatihan dan pengujian 


\section{PEMBAHASAN}

Tampilan antar muka dalam penelitian ini memiliki tiga halaman yaitu halaman depan, halaman pelatihan dan halaman pengujian. Halaman depan merupakan antar muka yang berisi menu-menu untuk menampilkan antar muka lainnya dalam sistem. Hasil implementasi halaman depan dapat dilihat pada Gambar 7(a). Halaman Pelatihan berguna untuk melakukan pelatihan sebuah citra agar sistem dapat mengenali ciri citra buah kelapa sawit yang mirip untuk kemudian diklasifikasikan sesuai kategori. Hasil rancangan halaman pelatihan dapat dilihat pada Gambar 7(b). Halaman pengujian merupakan proses pengujian sebuah citra untuk identifikasi citra tersebut masuk dalam kategori yang sesuai. Hasil tampilan rancangan pada halaman pengujian dapat dilihat pada Gambar 8.

(a)

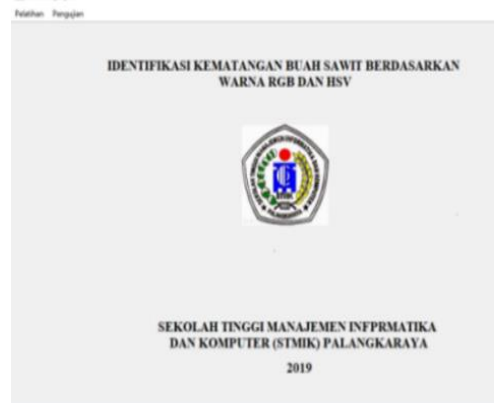

(b)

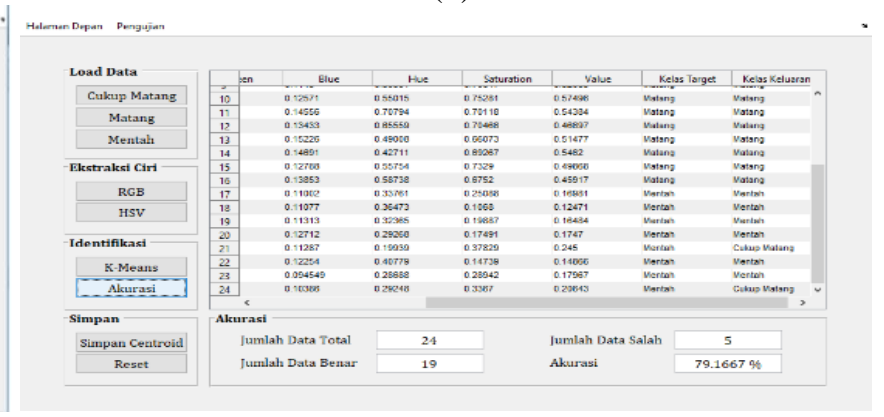

Gambar 7. (a) Tampilan Halaman Depan, (b)Tampilan Halaman Pelatihan



Gambar 8. Tampilan halaman pengujian

Proses yang dilakukan yaitu pelabelan, resize atau menyamakan ukuran serta mengubah citra RGB ke grayscale. Proses selanjutnya adalah segmentasi citra biner yang diperoleh dari citra grayscale kemudian diproses lagi citra HSV. Informasi terakhir dari pengolahan citra adalah ekstraksi ciri yang diperoleh dari nilai red, green, blue, hue, saturation dan value.

\subsection{Hasil Klasifikasi $K$-Means Clustering}

Hasil klasifikasi dengan menggunakan Metode K-Means Clustering untuk data latih ditunjukkan pada Tabel 1.

Tabel 1. Hasil klasifikasi K-Means clustering untuk data latih

\begin{tabular}{cccc}
\hline Data gambar & Hasil luaran manual & Hasil luaran sistem & Keterangan \\
\hline Gambar 1 & Cukup Matang & Cukup Matang & Benar \\
Gambar 2 & Cukup Matang & Matang & Salah \\
Gambar 3 & Cukup Matang & Matang & Salah \\
Gambar 4 & Cukup Matang & Cukup Matang & Benar \\
Gambar 5 & Cukup Matang & Matang & Salah \\
Gambar 6 & Cukup Matang & Cukup Matang & Benar
\end{tabular}




\begin{tabular}{cccc} 
Gambar 7 & Cukup Matang & Cukup Matang & Benar \\
Gambar 8 & Cukup Matang & Cukup Matang & Benar \\
Gambar 9 & Matang & Matang & Benar \\
Gambar 10 & Matang & Matang & Benar \\
Gambar 11 & Matang & Matang & Benar \\
Gambar 12 & Matang & Matang & Benar \\
Gambar 13 & Matang & Matang & Benar \\
Gambar 14 & Matang & Matang & Benar \\
Gambar 15 & Matang & Matang & Benar \\
Gambar 16 & Matang & Matang & Benar \\
Gambar 17 & Mentah & Mentah & Benar \\
Gambar 18 & Mentah & Mentah & Benar \\
Gambar 19 & Mentah & Mentah & Benar \\
Gambar 20 & Mentah & Mentah & Benar \\
Gambar 21 & Mentah & Cukup Matang & Salah \\
Gambar 22 & Mentah & Mentah & Benar \\
Gambar 23 & Mentah & Mentah & Benar \\
Gambar 24 & Mentah & Cukup Matang & Salah \\
\hline
\end{tabular}

Hasil klasifikasi dengan menggunakan Metode $K$-Means Clustering untuk data uji ditunjukkan pada Tabel 2.

Tabel 2. Hasil klasifikasi K-Means Clustering untuk data uji

\begin{tabular}{cccc}
\hline Data gambar & Hasil luaran manual & Hasil luaran sistem & Keterangan \\
\hline Gambar 1 & Cukup Matang & Mentah & Benar \\
Gambar 2 & Cukup Matang & Cukup Matang & Salah \\
Gambar 3 & Cukup Matang & Cukup Matang & Salah \\
Gambar 4 & Cukup Matang & Cukup Matang & Salah \\
Gambar 5 & Cukup Matang & Matang & Salah \\
Gambar 6 & Cukup Matang & Matang & Salah \\
Gambar 7 & Matang & Matang & Benar \\
Gambar 8 & Matang & Matang & Benar \\
Gambar 9 & Matang & Cukup Matang & Benar \\
Gambar 10 & Matang & Matang & Benar \\
Gambar 11 & Matang & Cukup Matang & Salah \\
Gambar 12 & Matang & Cukup Matang & Salah \\
Gambar 13 & Mentah & Mentah & Salah \\
Gambar 14 & Mentah & Cukup Matang & Salah \\
Gambar 15 & Mentah & Mentah & Benar \\
Gambar 16 & Mentah & Mentah & Benar \\
Gambar 17 & Mentah & Cukup Matang & Benar \\
Gambar 18 & Mentah & Mentah & Benar \\
Gambar 19 & Mentah & Cukup Matang & Salah \\
Gambar 20 & Mentah & Mentah & Benar \\
\hline
\end{tabular}

\subsection{Pengujian $K$-Means Clustering}

Pengklasifikasian tingkat kematangan buah kelapa sawit dengan menggunakan $K$-Means Clustering belum dikatakan baik sehingga perlu dilakukan pengujian tentang keakuratan dan error dari klasifikasi terhadap data latih dan data uji. Berikut adalah contoh proses perhitungan dengan $K$-Means Clustering pada sebuah hasil ekstraksi ciri. Terdapat 6 buah data gambar yang akan dikelompokkan menjadi 3 cluster, namakan $\mathrm{C} 1, \mathrm{C} 2$ dan $\mathrm{C} 3$. 
Tabel 3. Data hasil ekstraksi ciri

\begin{tabular}{cccc}
\hline Data Gambar & Red & Green & Blue \\
\hline 1 & 0,302 & 0,168 & 0,108 \\
2 & 0,470 & 0,206 & 0,081 \\
3 & 0,575 & 0,129 & 0,126 \\
4 & 0,544 & 0,136 & 0,146 \\
5 & 0,176 & 0,148 & 0,095 \\
6 & 0,204 & 0,158 & 0,104 \\
\hline
\end{tabular}

Pertama ditentukan nilai centroid secara acak, kemudian untuk mendapatkan jarak minimum digunakan rumus Euclidian Distance seperti pada Persamaan (7).

Diketahui centroid awal data:

$\begin{array}{llll}\text { C1 } & 0,302 & 0,168 & 0,108 \\ \text { C2 } & 0,575 & 0,129 & 0,126 \\ \text { C3 } & 0,176 & 0,148 & 0,095\end{array}$

Jarak minimum data centroid awal berdasarkan Tabel 2 adalah:

Cluster $1=\sqrt{(0,302-0,302)^{2}+(0,168-0,168)^{2}+(0,108-0,108)^{2}}=0$

Cluster $2=\sqrt{(0,302-0,575)^{2}+(0,168-0,129)^{2}+(0,108-0,126)^{2}}=0,276$

Cluster $3=\sqrt{(0,302-0,176)^{2}+(0,168-0,148)^{2}+(0,108-0,095)^{2}}=0,128$

Jarak minimum data gambar kedua adalah:

Cluster $1=\sqrt{(0,470-0,302)^{2}+(0,206-0,168)^{2}+(0,081-0,108)^{2}}=0,174$

Cluster $2=\sqrt{(0,470-0,575)^{2}+(0,206-0,129)^{2}+(0,081-0,126)^{2}}=0,137$

Cluster $3=\sqrt{(0,302-0,176)^{2}+(0,168-0,148)^{2}+(0,108-0,095)^{2}}=0,299$

Selanjutnya, jarak semua data dihitung dengan cara yang sama. Hasil perhitungan jarak keseluruhan pada iterasi pertama. Data kemudian dikelompokkan sesuai dengan cluster-nya, yaitu data yang memiliki jarak terpendek.

Tabel 4. Hasil iterasi 1

\begin{tabular}{ccccc}
\hline Data & C1 & C2 & C3 & Cluster \\
\hline 1 & $\mathbf{0}$ & 0,276 & 0,128 & 1 \\
2 & 0,174 & $\mathbf{0 , 1 3 7}$ & 0,299 & 2 \\
3 & 0,276 & $\mathbf{0}$ & 0,400 & 2 \\
4 & 0,247 & 0,037 & 0,371 & 2 \\
5 & 0,128 & 0,400 & $\mathbf{0}$ & 3 \\
6 & 0,098 & 0,372 & $\mathbf{0 , 0 3 1}$ & 3 \\
\hline
\end{tabular}

Karena 0 lebih kecil dari 0,276 dan 0,128 maka data pertama masuk pada cluster 1 . Selanjutnya karena 0,137 lebih kecil dari 0,174 dan 0,299 maka data kedua masuk pada cluster 2. Begitu juga dengan data ke lima yaitu 0 lebih kecil dari 0,128 dan 0,400 maka data ke lima masuk pada cluster 3.

Setelah data dikelompokkan, maka selanjutnya nilai centroid harus dihitung ulang untuk menentukan jarak minimum yang baru, berikut perhitungan centroidnya.

$$
\begin{aligned}
& C 1=\left(\frac{0,302+0,470}{2}\right),\left(\frac{0,168+0,206}{2}\right),\left(\frac{0,108+0,081}{2}\right)=(0,537,0,271,0,148) \\
& C 2=\left(\frac{0,575+0,544}{2}\right),\left(\frac{0,129+0,136}{2}\right),\left(\frac{0,126+0,146}{2}\right)=(0,847,0,197,0,199) \\
& C 3=\left(\frac{0,176+0,204}{2}\right),\left(\frac{0,148+0,158}{2}\right),\left(\frac{0,095+0,104}{2}\right)=(0,278,0,227,0,147)
\end{aligned}
$$


Jarak minimum dihitung kembali dengan menggunakan centroid baru untuk iterasi kedua, sehingga diperoleh.

Tabel 5. Hasil iterasi 2

\begin{tabular}{cccccc}
\hline Data & $\mathrm{C} 1$ & $\mathrm{C} 2$ & $\mathrm{C} 3$ & Iterasi 1 & Iterasi 2 \\
\hline 1 & 0,260 & 0,553 & $\mathbf{0 , 0 7 5}$ & 1 & 3 \\
2 & $\mathbf{0 , 1 1 5}$ & 0,395 & 0,204 & 2 & 1 \\
3 & $\mathbf{0 , 1 4 9}$ & 0,290 & 0,313 & 2 & 1 \\
4 & $\mathbf{0 , 1 3 5}$ & 0,314 & 0,281 & 2 & 1 \\
5 & 0,385 & 0,681 & $\mathbf{0 , 1 3 9}$ & 3 & 3 \\
6 & 0,354 & 0,651 & $\mathbf{0 , 1 1 0}$ & 3 & 3 \\
\hline
\end{tabular}

Karena iterasi 1 dan iterasi 2 masih berubah maka dilakukan perhitungan untuk iterasi seterusnya sampai iterasi tidak berubah dengan cara yang sama. Berdasarkan pelatihan sebanyak 24 kali untuk data latih diperoleh 19 data benar sehingga tingkat keakuratan yang dihasilkan $79.16 \%$, sedangkan pada pengujian sebanyak 20 kali data uji diperoleh 10 data benar sehingga tingkat keakuratannya adalah $50 \%$. Dengan demikian tingkat keakuratan total K-Means Clustering yang digunakan untuk mengklasifikasikan tingkat kematangan buah kelapa sawit pada data uji dan data latih $64.58 \%$.

\section{KESIMPULAN}

Berdasarkan hasil penelitian dan pembahasan yang telah dilakukan, maka diperoleh kesimpulan sebagai berikut:

a. Proses identifikasi kematangan buah kelapa sawit dengan menggunakan metode $K$-means Clustering ini mampu mengenali objek citra buah kelapa sawit berdasarkan tingkat kematangan yaitu mentah, cukup matang, dan matang.

b. Hasil identifikasi kematangan buah kelapa sawit dengan algoritma $K$-means Clustering diperoleh tingkat keakuratan untuk data uji sebesar $79.16 \%$ dan tingkat keakuratan untuk data latih sebesar 50\%, sehingga tingkat keakuratan total keduanya adalah sebesar $64.58 \%$.

\section{DAFTAR PUSTAKA}

[1] F. Dianto, D. Efendi, and A. Wachjar, "Pengelolaan Panen Kelapa Sawit (Elaeis guineensis Jacq.) Pelantaran Agro Estate, Kota Waringin Timur, Kalimantan Tengah," Bul. Agrohorti, vol. 5, no. 3, pp. 410-417, 2017, doi: 10.29244/agrob.v5i3.19574.

[2] B. Derriansyah, "Indonesia Negara Penghasil Minyak Sawit Terbesar Dunia, 43 Juta MT Per Tahun," 2018. https://metropekanbaru.com/indonesia-negara-penghasil-minyak-sawitterbesar-dunia-43-juta-mt-per-tahun (accessed May 03, 2019).

[3] H. A. Priyambodo and S. Sastrowiratno, "Manajemen Panen Kelapa Sawit (Elais guineensis Jacq.) di Kebun Sei Galuh PT. Perkebunan Nusantara V Kec.Tapung, Kab. Kampar, Provinsi Riau," J. Agromast, vol. 2, 2017.

[4] Z. May and M. H. Amaran, "Automated ripeness assessment of oil palm fruit using RGB and fuzzy logic technique," in Proceedings of the 13th WSEAS international conference on Mathematical and computational methods in science and engineering, 2011, pp. 52-59.

[5] A. Mishra, P. Asthana, and P. Khanna, "the Quality Identification of Fruits in Image Processing Using Matlab," Int. J. Res. Eng. Technol., vol. 03, no. 22, pp. 92-95, 2014, doi: 10.15623/ijret.2014.0322019.

[6] Masykur, "Pengembangan Industri Kelapa Sawit Sebagai Penghasil Energi Bahan Alternatif dan Mengurangi Pemanasan Global," J. Reformasi, vol. 3, pp. 96-107, 2013.

[7] M. Widyaningsih, "Identifikasi Kematangan Buah Apel Dengan Gray Level CoOccurrence Matrix (GLCM)," J. SAINTEKOM, vol. 6, no. 1, p. 71, 2017, doi: 
10.33020/saintekom.v6i1.7.

[8] R. Ravikumar and Dr.V.Arulmozhi, "Digital Image Processing- A Quick Review," Int. J. Intell. Comput. Technol., vol. 2, no. 2, pp. 16-24, 2019.

[9] M. Yogi, I. Pendahuluan, and A. P. Aplikasi, "Aplikasi Deteksi Kematangan Buah Semangka Berbasis," vol. 3, no. 6, 2016.

[10] A. Fauzan, "Ruang Warna Hue Saturation Value (HSV) serta Proses Konversinya," 2015. https://www.kitainformatika.com/2015/01/ruang-warna-hue-saturation-value-hsv.html.

[11] S. Naeem and A. Wumaier, "Study and Implementing K-mean Clustering Algorithm on English Text and Techniques to Find the Optimal Value of K," Int. J. Comput. Appl., vol. 182, no. 31, pp. 7-14, 2018, doi: 10.5120/ijca2018918234.

[12] M. Anggara, H. Sujiani, and N. Helfi, "Pemilihan Distance Measure Pada K-Means Clustering Untuk Pengelompokkan Member Di Alvaro Fitness," J. Sist. dan Teknol. Inf., vol. 1, no. 1, pp. 1-6, 2016.

\section{Biodata Penulis}

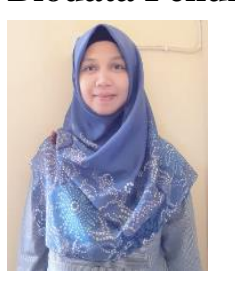

Elok Faiqotul Himmah, S.Si., M.Sc., lahir di Kuala Kapuas pada tanggal 9 Maret 1985. Penulis merupakan lulusan S2 Matematika Universitas Gadjah Mada pada tahun 2017. Saat ini penulis menjabat sebagai dosen di Program Studi Teknik Informatika, STMIK Palangkaraya.

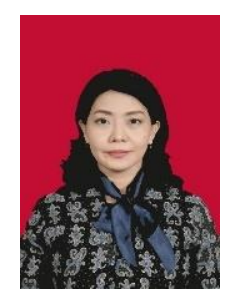

Maura Widyaningsih, S.Kom., M.Cs, lahir di Semarang pada tanggal 23 Februari 1975. Penulis merupakan lulusan S2 Ilmu Komputer Universitas Gadjah Mada pada tahun 2014. Saat ini penulis menjabat sebagai Kepala UP3M STMIK Palangkaraya.

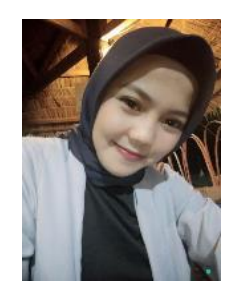

Maisaroh, S.Kom, lahir di Purworejo pada tanggal 2 November 1996. Penulis merupakan lulusan S1 Teknik Informatika STMIK Palangkaraya pada tahun 2019. 